\title{
INTELLECTUAL CAPITAL TERHADAP FINANCIAL PERFORMANCE DAN SUSTAINABLE GROWTH
}

\author{
Dian Agustia \\ dian.agustia@feb.unair.ac.id \\ Universitas Airlangga \\ Nur Fadjrih Asyik \\ Sekolah Tinggi Ilmu Ekonomi Indonesia (STIESIA) Surabaya \\ Nidia Midiantari \\ Universitas Airlangga
}

\begin{abstract}
This study aims to examine the effect of intellectual capital on company financial performance and company sustainability growth. This study uses manufacturing companies listed on the Indonesia Stock Exchange in 2014-2018. This study found that the components of intellectual capital have an effect on company performance, this is because well-managed intellectual capital is the main driver of increasing company performance and is also supported by superior intellectuals that will have an impact on the company's sustainable growth. Intellectual capital which includes human capital, structural capital, and relational capital is able to improve the company's financial performance, which in turn will be able to increase investment. This investment will ultimately increase the market reaction which is reflected in the company's stock price (company value). Intellectual capital is also an impetus for companies to be able to grow sustainably, especially in terms of human capital owned by the company. Companies must continue to develop and empower their potential resources in order to advance the company so that the company can win in the competition which is getting heavier.
\end{abstract}

Key words: intellectual capital, financial performance, sustainable growth

\begin{abstract}
ABSTRAK
Penelitian ini bertujuan untuk menguji pengaruh modal intelektual terhadap kinerja keuangan perusahaan dan pertumbuhan keberlanjutan perusahaan. Penelitian ini menggunakan perusahaan manufaktur yang terdaftar pada Bursa Efek Indonesia pada tahun 2014-2018. Penelitian ini menemukan bahwa komponen dari modal intelektual berpengaruh terhadap kinerja perusahaan, hal ini dikarenakan modal intelektual yang dikelola dengan baik menjadi pendorong utama meningkatnya kinerja perusahaan serta didukung juga dengan intellektual yang unggul akan berdampak pada pertumbuhan keberlanjutan perusahaan. Intellectual capital yang meliputi human capital, structural capital, dan relational capital mampu meningkatkan kinerja keuangan perusahaan, yang selanjutnya akan mampu menambah investasi perusahaan. Investasi tersebut pada akhirnya akan meningkatkan reaksi pasar yang terefleksi pada harga saham perusahaan (nilai perusahaan). Intellectual capital juga menjadi sebuah dorongan bagi perusahaan agar mampu tumbuh berkembang secara berkelanjutan, khususnya pada aspek human capital yang dimiliki perusahaan. Perusahaan harus terus mengembangkan dan memberdayakan sumber daya potensial yang dimiliki dalam rangka untuk memajukan perusahaan sehingga perusahaan dapat memenangkan persaingan yang semakin ketat.
\end{abstract}

Kata kunci: modal intelektual; kinerja keuangan; pertumbuhan berkelanjutan 


\section{PENDAHULUAN}

Dengan pertumbuhan yang cepat dari perusahaan yang maju secara teknologi dalam ekonomi berbasis pengetahuan, manajemen perusahaan telah menaruh perhatian lebih pada pentingnya modal intelektual atau Intellectual Capital (IC) (Bontis, 2001; Bontis et al., 2000). IC dianggap sebagai pendorong daya saing perusahaan dan keberlanjutan finansial. Intellectual capital atau modal intelektual menggambarkan sumber pengetahuan atau aset tidak berwujud dari sebuah organisasi (Duff, 2017). Komponen yang membangun intellectual capital adalah human capital, structural capital, dan relational capital. Ketiga komponen tersebut memiliki peranan masing-masing untuk menciptakan nilai dan maanfaat bagi perusahaan.

Pesatnya perubahan dan kemajuan teknologi, mendorong perusahaan untuk memberi perhatian lebih pada intellectual capital. Smriti dan Das (2018) menyatakan bahwa intellectual capital adalah sumber daya internal perusahaan dengan karakteristik tertentu yang mampu menciptakan nilai bagi perusahaan Berdasarkan pandangan berbasis sumber daya (RBV), perusahaan dengan sumber daya yang berharga dan langka lebih mungkin untuk mendapatkan keunggulan kompetitif yang berkelanjutan. Sumber daya ini dapat memungkinkan perusahaan untuk mempertahankan sumber daya manusia, meningkatkan proses, mempertahankan kontak dengan pelanggan dan pemasok, dan menghasilkan inovasi yang lebih besar. Organisasi diharapkan untuk melakukan aktivitas yang dianggap penting oleh stakeholder dan melaporkan kembali semua aktivitas tersebut kepada stakeholder untuk memberikan keuntungan. Keberadaan teori stakeholder membantu manajer perusahaan mengerti lingkungan perusahaan mereka dan melakukan pengelolaan perusahaan yang lebih efektif

Intellectual capital dianggap sebagai pendorong kinerja perusahaan sehingga menciptakan keunggulan kompetitif dan keberlanjutan dalam bisnis (Xu dan Wang, 2018). Forte et al. (2017) dan Meles et al. (2016) membuktikan intellectual capital berpengaruh terhadap kinerja perusahaan, dimana kinerja diukur menggunakan kinerja keuangan. Perusahaan yang memiliki sumber daya potensial akan memiliki keunggulan bersaing dan mampu mengarahkan perusahaan untuk memiliki kinerja jangka panjang yang baik.

Berdasarkan penelitian terdahulu Ginesti et al. (2018), intellectual capital terbukti memiliki pengaruh signifikan positif terhadap kinerja perusahaan. Menurut Meles et al. (2016) human capital menjadi komponen intellectual capital yang paling berpengaruh terhadap kinerja perusahaan. Nimtrakoon (2015) menunjukkan HCE dan CEE yang paling berpengaruh terhadap kinerja perusahaan, sedangkan menurut Bontis et al. (2018) komponen intellectual capital yang paling berpengaruh adalah human capital dan relational capital. Kemudian penelitian dari Jordao dan Almeida (2017) berhasil membuktikan adanya pengaruh intellectual capital terhadap kinerja keuangan jangka panjang.

Intellectual capital dianggap sebagai penghasil kekayaan dan penggerak kinerja keuangan sehingga menciptakan keunggulan kompetitif dan keberlanjutan perusahaan (Xu dan Wang, 2018). Forte et al. (2017) menganggap bahwa intellectual capital sebagai internal saham (kompetensi, keterampilan, kepemimpinan, prosedur, pengetahuan) dan eksternal saham (gambar, merek, aliansi, kepuasan pelanggan) yang berwujud dinamis saling tersedia untuk sebuah organisasi, yang mampu mengejar penciptaan nilai yang berkesinambungan. Dengan kata lain, pengelolaan intellectual capital yang baik akan menciptakan sustainable growth perusahaan.

Konsep sustainable growth menjadi terkenal berkat penelitian Higgins, 1977 (dalam Mukherjee dan Sen, 2019). Tingkat kemampuan perusahaan yang menggunakan dana internalnya, diasumsikan kegiatan produksi perusahaan tidak perlu 
bergantung dana dari pihak eksternal, sehingga perusahaan diharapkan dapat terus bertumbuh dan bertahan. Penggunaan sustainable growth dapat bermanfaat bagi perusahaan sebagai alat perencanaan keuangan yang efektif untuk kelangsungan hidup perusahaan. Hal tersebut dikarenakan dengan menggunakan sustainable growth, investor dan manajer dapat mengukur apakah rencana pertumbuhan masa depan perusahaan sesuai dengan realita kinerja perusahaan saat ini (Amouzesh et al., 2011).

Berdasarkan penelitian terdahulu $\mathrm{Xu}$ dan Wang (2018) perusahaan dengan intellectual capital yang lebih besar cenderung memiliki sustainable growth yang lebih tinggi. Masing-masing elemen dari intellectual capital juga diuji pengaruhnya terhadap sustainable growth perusahaan, relational capital merupakan elemen intellectual capital yang paling berpengaruh. Namun, hasil yang berbeda ditunjukkan oleh penelitian Mukherjee dan Sen (2019). Intellectual capital dan komponen-komponennya terbukti memiliki pengaruh terhadap sustainable growth perusahaan.

Tujuan utama dari bisnis ini adalah untuk memaksimalkan kekayaan pemegang sahamnya. Laba dapat memberikan kekuatan dalam pengembangan bisnis yang berkelanjutan, tetapi pencapaiannya tidak harus pada semua biaya. Mempelajari kinerja keuangan yang berkelanjutan melibatkan penilaian kemampuan pengembangan perusahaan di masa depan. Meskipun manajer perusahaan dapat meningkatkan kinerja keuangan perusahaan, mereka tidak mungkin benar-benar memahami kemampuan pengembangan berkelanjutan jangka panjang perusahaan, terutama efek IC terhadap pertumbuhan berkelanjutan (Cantele dan Zardini, 2018). Oleh karena itu, sangat penting untuk mempelajari hubungan keberlanjutan ICbisnis dalam ilmu ekonomi.

Karena persaingan yang signifikan dalam industri manufaktur secara global, industri manufaktur di negara berkembang menghadapi banyak tekanan baik secara internal ataupun eksternal, termasuk yang berkaitan dengan keberlanjutan (Herrmann et al., 2014). Industri manufaktur tersebut membutuhkan keterampilan khusus dan tunduk pada pengetahuan dan kemampuan organisasi secara implisit (Sharabati et al., 2010). Selain itu, daya tahan industri manufaktur sebagian besar bergantung pada jumlah karyawan yang terampil dan volume modal fisik (Smriti dan Das, 2018). Hal ini membuat sektor manufaktur menjadi industri yang menarik untuk melakukan penelitian IC (Andreeva dan Garanina, 2016; Khalique et al., 2015).

Penelitian mengkonfirmasi bahwa setiap perusahaan harus mengelola sumber daya ini untuk menciptakan keunggulan kompetitif. Perusahaan disebut memiliki keunggulan kompetitif jika mampu menciptakan nilai ekonomis yang lebih tinggi dibandingkan pesaingnya. Sehingga sejalan resource-based view theory yang diperkenalkan oleh Barney (1991), yang menyatakan bahwa perusahaan memiliki sumber daya yang menjadikan perusahaan memiliki keunggulan kompetitif dan mampu mengarahkan perusahaan untuk memiliki kinerja jangka panjang yang baik (Barney, 1991). Kemudian perusahaan diharapkan untuk melakukan aktivitas yang dianggap penting oleh stakeholder dan melaporkan kembali semua aktivitas tersebut kepada stakeholder untuk memberikan keuntungan. Hal ini sejalan dengan stakeholder theory yang diperkenalkan Freeman (1984), yang menyatakan bahwa manajer diharuskan untuk mampu mengelola perusahaan secara maksimal, khususnya dalam upaya penciptaan nilai bagi perusahaan dan meminimalkan kerugian bagi stakeholder. Pengelolaan yang baik dan maksimal atas seluruh potensi yang dimiliki perusahaan, akan menciptakan nilai tambah yang selanjutnya akan mendorong kinerja perusahaan untuk mencapai sustainable growth.

Tujuan dari penelitian ini adalah untuk menyelidiki secara empiris pengaruh IC 
terhadap kinerja keuangan, dan pengaruh IC terhadap pertumbuhan berkelanjutan, menggunakan perusahaan manufaktur yang terdaftar di Indonesia. Selanjutnya, kami menganalisis dampak masing-masing komponen dari IC.

Rumusan masalah penelitian ini adalah apakah intellectual capital berpengaruh terhadap financial performance dan companies' sustainable growth?.

Tujuan penelitian adalah untuk menganalisis pengaruh intellectual capital terhadap financial performance dan companies' sustainable growth.

\section{TINJAUAN TEORETIS}

\section{Resources-Based View Theory}

Barney (1991) menyatakan bahwa perusahaan memiliki sumber daya yang menjadikan perusahaan memiliki keunggulan kompetitif dan mampu mengarahkan perusahaan untuk memiliki kinerja jangka panjang yang baik. Terdapat tiga jenis sumber daya yang dimiliki perusahaan yang meliputi sumber daya fisik (seperti bahan baku, teknologi, pabrik, peralatan), sumber daya manusia (seperti pelatihan, pengalaman, pengetahuan), dan sumber daya organisasi (seperti struktur formal). Resources-based view theory menganggap perusahaan adalah kumpulan dari semua sumber daya tersebut. Sumber daya dan cara perusahaan menggabungkannya akan membuat perusahaan berbeda dengan perusahaan lain sehingga memungkinkan perusahaan memperoleh keunggulan kompetitif serta mampu bersaing dalam waktu cukup lama.

Setiap perusahaan harus mengelola sumber daya ini untuk menciptakan keunggulan kompetitif. Perusahaan disebut memiliki keunggulan kompetitif jika mampu menciptakan nilai ekonomis yang lebih tinggi dibandingkan pesaingnya (Peteraf dan Barney, 2003). Lebih lanjut dijelaskan oleh Barney (1991), agar menjadi sumber daya yang potensial, maka sumber daya harus memenuhi empat kriteria yaitu, bernilai, langka, tidak dapat ditiru, dan tidak dapat digantikan. Berdasarkan teori ini dapat mengindikasikan bahwa intellectual capital memenuhi kriteria-kriteria sebagai sumber daya yang unik untuk menciptakan keunggulan kompetitif dan meningkatkan kinerja perusahaan sehingga mampu menciptakan nilai tambah yang bermanfaat bagi sustainable growth.

\section{Stakeholder Theory}

Organisasi diharapkan melakukan aktivitas yang dianggap penting oleh stakeholder dan melaporkan kembali semua aktivitas tersebut kepada stakeholder untuk memberikan keuntungan. Hal ini sejalan dengan pendapat Ghozali dan Chariri (2007), bahwa perusahaan tidak hanya beroperasi untuk kepentingan sendiri tetapi harus memberikan manfaat bagi stakeholder seperti pemegang saham, konsumen, supplier, masyarakat, pemerintah, dan pihak lainnya.

Keberadaan teori stakeholder membantu manajer perusahaan mengerti lingkungan perusahaan mereka dan melakukan pengelolaan perusahaan yang lebih efektif. Manajer harus mengelola organisasi untuk keuntungan seluruh stakeholder. Hal ini sejalan dengan pendapat Ulum (2015) bahwa manajer diharuskan untuk mampu mengelola perusahaan secara maksimal, khususnya dalam upaya penciptaan nilai bagi perusahaan dan meminimalkan kerugian bagi stakeholder. Pengelolaan yang baik dan maksimal atas seluruh potensi yang dimiliki perusahaan, akan menciptakan nilai tambah yang selanjutnya akan mendorong kinerja perusahaan untuk mencapai sustainable growth.

\section{Financial Performance}

Setiap perusahaan ataupun organisasi dituntut untuk memiliki kinerja yang baik. Hal tersebut menjadi tuntutan utama dalam menjalankan sebuah perusahaan agar terus bertahan. Kinerja perusahaan dapat dinilai menggunakan pengukuran kinerja keuangan dan non keuangan. Menurut Rakhiemah dan Agustia (2009), kinerja keuangan ada- 
lah kinerja dari perusahaan secara relatif dalam suatu industri yang ditandai dengan return tahunan industri bersangkutan. Hasil penilaian kinerja perusahaan berguna dalam pengambilan keputusan serta dapat digunakan untuk melihat sejauh mana keberhasilan pengelolaan sumber daya.

Rasio pengukuran kinerja keuangan sangat beragam, salah satunya adalah ROE. Return on Equity (ROE) merupakan rasio yang digunakan untuk menilai sejauh mana perusahaan menggunakan sumber daya yang dimiliki untuk memberikan laba terhadap ekuitas yang dimiliki (Fahmi, 2012). Rasio ini menjelaskan efektivitas perusahaan dalam memperoleh manfaat dari modal yang dimiliki. Hal ini sejalan dengan pendapat Kasmir (2015) tujuan penggunaan rasio $\mathrm{ROE}$ adalah mengukur produktivitas modal perusahaan yang digunakan untuk menghasilkan laba.

\section{Sustainable Growth}

Konsep sustainable growth menjadi terkenal berkat penelitian Higgins, 1977 (Mukherjee dan Sen, 2019). Higgins mengukur sustainable growth dengan SGR (sustainable growth rate) yang merupakan tingkat maksimum dimana perusahaan dapat menggunakan dana internalnya sendiri untuk mencapai pertumbuhannya tanpa meminjam uang dari bank atau lembaga keuangan ( $\mathrm{Xu}$ dan Wang, 2018). Dengan kemampuan perusahaan menggunakan dana internalnya, diasumsikan kegiatan produksi perusahaan tidak perlu bergantung dana dari pihak eksternal, sehingga perusahaan diharapkan dapat terus bertumbuh dan bertahan. Menurut Arora et al. (2018), sustainable growth merupakan pendekatan berwawasan ke depan yang bermanfaat bagi para manajer dalam menyeimbangkan strategi operasional dan keuangan mereka. Penggunaan sustainable growth dapat bermanfaat bagi perusahaan sebagai alat perencanaan keuangan yang efektif untuk kelangsungan hidup perusahaan.

\section{Intellectual Capital}

Pertumbuhan perusahaan yang berbasis pada pengetahuan dan teknologi, telah meningkatkan perhatian perusahaan terhadap intellectual capital. Intellectual capital dianggap sebagai penghasil kekayaan dan penggerak kinerja keuangan sehingga menciptakan keunggulan kompetitif dan keberlanjutan perusahaan (Xu dan Wang, 2018). Hal ini terjadi karena intellectual capital merupakan aset tidak berwujud yang dimiliki oleh perusahaan dimana penciptaan pengetahuan dan disebar secara internal dan eksternal (Uzliawati dan Djati, 2015). Dzenopoljac et al. (2017) bahwa jika intellectual capital dikelola dengan baik, akan memberikan nilai manfaat seperti yang diinginkan pasar. Intellectual capital dibangun oleh tiga elemen penting, yaitu human capital, structural capital, dan relational capital.

Human capital merupakan elemen kunci dari intellectual capital dan salah satu sumber daya paling penting untuk keunggulan kompetitif (Yaseen et al., 2016). Menurut Meles et al. (2016), human capital adalah modal yang diwakilkan oleh karyawan untuk menciptakan intellectual capital melalui kompetensi, kemampuan, dan ketangkasan karyawan. Keberadaan human capital juga harus didukung dengan keberadaan elemen intellectual capital lainnya yaitu structural capital. Hal ini sejalan dengan pendapat Bontis et al. (2018) yang menyatakan bahwa structural capital adalah infrastruktur yang menunjang sumber daya manusia dan pengetahuan, seperti perilaku inovatif, sertifikasi keberlanjutan dan kualitas, serta budaya perusahaan. Menurut Smriti dan Das (2018) structural capital merupakan modal organisasi yang didalamnya meliputi sistem, struktur, dan proses, contohnya database, proses manajemen, serta rencana perusahaan. 


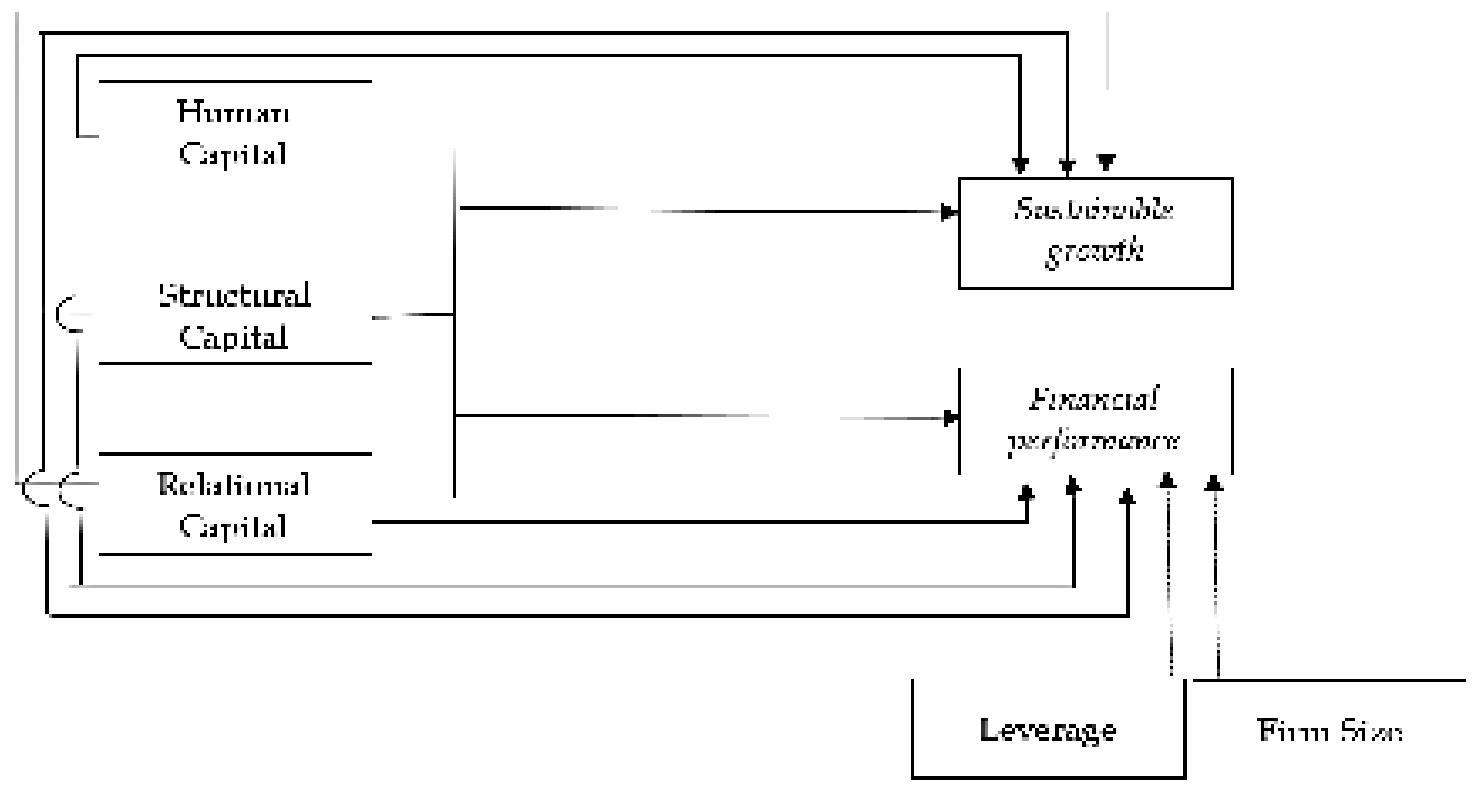

Gambar 1

\section{Kerangka Konseptual}

Perusahaan dengan structural capital yang kuat dapat menemukan kesesuaian yang lebih baik dengan human capital terhadap relational capital (Yaseen et al., 2016). Andreeva dan Garanina (2016), relational capital mengacu pada nilai tambah yang tertanam dalam hubungan organisasi dengan pelanggan, pemasok, dan pemang$\mathrm{ku}$ kepentingan lainnya. Dalam beberapa penelitian lain relational capital ini dikenal dengan istilah customer capital. Sejalan dengan Smriti dan Das (2018), relational capital adalah modal yang mengelola dan mengatur hubungan eksternal perusahaan, termasuk hubungan dengan pemasok, pelanggan, dan pemangku kepentingan.

Midiantari dan Agustia (2020) menunjukkan bahwa untuk meningkatkan nilai perusahaan, diperlukan upaya dan dukungan dari manajer dan karyawan untuk tetap memperhatikan kualitas pekerjaan dan memaksimalkan segala yang mereka kuasai di bidangnya, hal tersebut merupakan modal intelektual yang dimiliki perusahaan untuk dimanfaatkan dalam rangka kemajuan perusahaan.

Penelitian ini menguji pengaruh intellectual capital terhadap sustainable growth dan financial performance. Sustainable growth dan financial performance nantinya akan dikontrol dengan leverage perusahaan dan ukuran perusahaan. Berdasarkan uraian yang dikemukakan di atas, kerangka konseptual dalam penelitian ini disajikan pada gambar 1.

\section{Pengembangan Hipotesis}

Resource-based view theory menyatakan sumber daya perusahaan harus memenuhi empat kriteria yaitu bernilai, langka, tidak dapat ditiru, dan tidak ada sumber daya pengganti agar menjadi sumber daya yang unik dan memiliki keunggulan kompetitif (Barney, 1991). Kinerja perusahaan berkaitan dengan pemanfaatan sumber daya yang tepat, itu sebabnya human capital dianggap sebagai komponen penting untuk meningkatkan kinerja perusahaan.

Beberapa penelitian sebelumnya menguji tentang bagaimana IC terkait dengan financial performance perusahaan. Nimtrakoon (2015) berpendapat bahwa IC dapat secara positif meningkatkan kinerja perusahaan saat ini dan di masa depan, dan hasil ini juga konsisten untuk negara-negara ASEAN. Anghel et al. (2018) membuktikan bahwa, pada level 24 perusahaan biotek selama 2002-2014, IC (diukur dengan 
market-to-book ratio) berkorelasi positif dengan indikator kinerja keuangan. Jika IC adalah pendorong daya saing perusahaan, hal itu akan berkontribusi pada kinerja keuangan perusahaan. Oleh karena itu, hipotesis pertama sebagai berikut:

\section{$\mathrm{H}_{1}$ : Intellectual capital berpengaruh terhadap financial performance}

Penelitian yang dilakukan oleh Nimtrakoon (2015) berhasil membuktikan bahwa human capital mampu mendorong kinerja perusahaan. Sejalan dengan penelitian yang dilakukan oleh Ozkan et al. (2016), Bontis et al. (2018), serta Andreeva dan Garanina (2016) human capital memiliki pengaruh signifikan terhadap kinerja perusahaan. Keberadaan human capital terbukti paling berpengaruh terhadap kinerja perusahaan dibandingkan komponen intellectual capital lainnya (Meles et al., 2016).

Structural capital adalah kemampuan perusahaan dalam memenuhi proses rutinitas perusahaan untuk mendukung produktivitas dan menghasilkan kinerja bisnis (Yaseen et al., 2016). Ginesti et al. (2018) serta Andreeva dan Garanina (2016) berhasil membuktikan adanya pengaruh signifikan antara structural capital dan kinerja perusahaan. Hal ini sejalan dengan Smriti dan Das (2018) yang menyatakan pemanfaat structural capital yang efisien, akan mendorong peningkatan kinerja perusahaan.

Menjaga hubungan baik dengan pihak eksternal sangat penting bagi kelangsungan hidup perusahaan. Penelitian yang dilakukan oleh Ozkan et al. (2016) menyatakan bahwa relational capital merupakan elemen intellectual capital yang paling berpengaruh terhadap kinerja perusahaan dibandingkan dengan elemen lainnya. Sejalan dengan penelitian Ginesti et al. (2018) serta Smriti dan Das (2018), semakin efisien pemanfaat relational capital akan mendorong kinerja perusahaan.

Investor dapat menempatkan nilai yang berbeda pada setiap komponen VAIC. CEE digunakan untuk mengukur dimensi modal fisik (physical capital). HCE dan SCE adalah pengukuran efisiensi nilai tambah oleh HC dan SC. Smriti dan Das (2018) dan Nimtrakoon (2015) berpendapat bahwa SCE berkorelasi positif dengan nilai pasar perusahaan. Ismail dan Karem (2011) menemukan bahwa CEE dan HCE secara signifikan berkorelasi dengan kinerja bank di Bahrain, dan bahwa tidak ada hubungan antara SCE dan kinerja keuangan. Dengan demikian, berdasarkan argumen di atas, maka dirumuskan hipotesis kedua sebagai berikut:

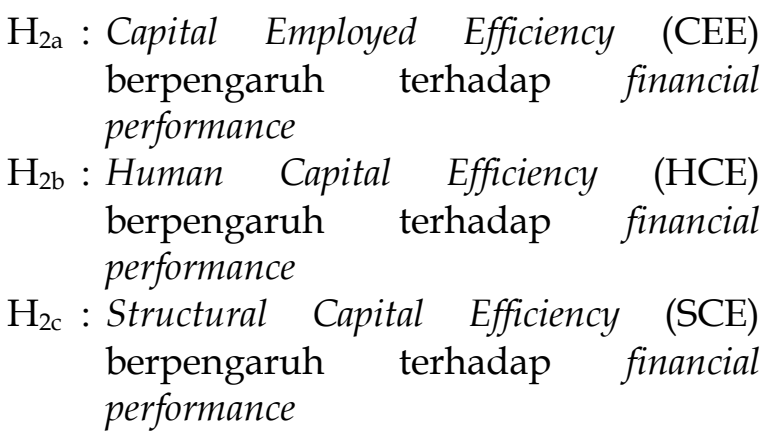

Konsep sustainable growth (SGR) menggambarkan pertumbuhan optimal dari perspektif keuangan dengan mengasumsikan strategi yang diberikan dengan kondisi kerangka keuangan yang jelas. Secara sederhana, perusahaan dapat menggunakan dana internal untuk mencapai partumbuhannya tanpa meminjam uang dari bank atau lembaga keuangan. Dalam konteks Industri 4.0, modal inovatif (R\&D dan hak kekayaan intelektual) adalah penentu alokasi sumber daya internal, pengembangan produk baru, dan perluasan pasar baru. Kegiatan RdanD dengan risiko tinggi mengharuskan perusahaan untuk membuat jaminan sistem yang saling berintegrasi, dan SC dapat memberikan jaminan lingkungan untuk pertumbuhan perusahaan manufaktur. Di sisi lain, untuk perusahaan manufaktur, HC dan SC adalah sumber daya unik yang sulit ditiru oleh pesaing. Oleh karena itu, IC adalah kekuatan pendorong utama untuk pertumbuhan perusahaan manufaktur yang berkelanjutan. 
Berdasarkan argumen tersebut ditetapkan kipotesis ketiga sebagai berikut:

$\mathrm{H}_{3}$ : Intellectual capital berpengaruh terhadap sustainable growth

Dampak ketiga komponen IC terhadap pertumbuhan berkelanjutan perusahaan dapat beragam. Semisal modal fisik tidak langka, dan perusahaan dapat dengan cepat dan bebas memperoleh sumber daya ini dari pasar. Perusahaan manufaktur umumnya memiliki sebagian besar investasi dalam aset berwujud dan sangat bergantung pada karyawan.

Resource-based view theory menyatakan bahwa perusahaan memiliki sumber daya yang mampu menjadikan perusahaan memiliki keunggulan bersaing dan mengarahkan perusahaan untuk memiliki kinerja jangka panjang yang baik (Barney, 1991). Perusahaan membutuhkan segala kemampuan tersebut dari karyawan untuk efisiensi dalam produksi, menciptakan keunggulan kompetitif hingga mencapai sustainable growth. Hal ini juga sesuai dengan stakeholder theory, dimana perusahaan tidak hanya beroperasi untuk kepentingan sendiri tetapi harus memberikan manfaat bagi stakeholder seperti pemegang saham, konsumen, supplier, masyarakat, pemerintah dan pihak lainnya (Ghozali dan Chariri, 2007). Keberadaan teori stakeholder membantu manajer perusahaan mengerti lingkungan perusahaan mereka dan melakukan pengelolaan perusahaan yang lebih efektif. Manajer harus mengelola organisasi untuk keuntungan seluruh stakeholder. Dalam penelitian $\mathrm{Xu}$ et al. (2020) berhasil membuktikan adanya pengaruh signifikan intellectual capital terhadap sustainable growth. Hal ini sejalan dengan penelitian $\mathrm{Xu}$ dan Wang (2018) menyebutkan bahwa human capital sebagai salah satu komponen intellectual capital yang terbukti mampu memberikan pengaruh positif pada sustainable growth perusahaan.

Structural capital adalah sumber daya perusahaan yang meliputi prosedur, database, rutinitas, dan budaya perusahaan
(Meles et al., 2016). Keberadaan intellectual capital terbukti mempengaruhi sustainable growth secara signifikan ( $\mathrm{Xu}$ dan Wang, 2018). Lebih lanjut penelitian tersebut menjelaskan bahwa structural capital mampu memberikan pengaruh positif terhadap sustainable growth perusahaan. Dengan pengelolaan database, sistem informasi dan strategi perusahaan yang baik, akan memberikan dampak yang baik bagi sustainable growth perusahaan.

Duff (2018) menyebutkan bahwa relational capital meliputi hubungan eksternal perusahaan dengan pelanggan, pemasok, maupun regulator dan segala persepsi pihak eksternal terhadap perusahaan diantaranya, citra perusahaan, loyalitas dan kepuasan pelanggan, serta reputasi perusahaan. Terciptanya reputasi dan citra perusahaan yang baik serta loyalitas dan kepuasan pelanggan, hal ini akan menjadi modal yang bagus bagi perusahaan dalam mengoperasikan perusahaan untuk mencapai sustainable growth perusahaan. Relational capital sebagai salah satu komponen intellectual capital terbukti mampu memberikan pengaruh terhadap sustainable growth, bahkan menjadi komponen yang paling berpengaruh dibandingkan komponen yang lain ( $\mathrm{Xu}$ dan Wang, 2018). Sejalan dengan penelitian Mukherjee dan Sen (2019), relational capital memberikan dampak positif terhadap sustainable growth perusahaan. Dengan demikian, hipotesis keempat dirumuskan sebagai berikut:

$\mathrm{H}_{4 \mathrm{a}}$ : Capital Employed Efficiency (CEE) berpengaruh terhadap sustainable growth

$\mathrm{H}_{4 \mathrm{~b}}$ : Human Capital Efficiency (HCE) berpengaruh terhadap sustainable growth

$\mathrm{H}_{4 \mathrm{c}}$ : Structural Capital Efficiency (SCE) berpengaruh terhadap sustainable growth

\section{METODE PENELITIAN}

Sampel dalam penelitian ini terdiri atas perusahaan manufaktur yang terdaftar di BEI untuk periode 2014-2018. Sumber data 
dalam penelitian ini diperoleh melalui laporan tahunan perusahaan. Data keuangan diperoleh dari website www.idx.co.id. Selanjutnya, peneliti menerapkan kriteria pemilihan sampel sebagai berikut. Pertama, kecualikan semua perusahaan dalam industri perdagangan, jasa, dan investasi (SIC 5), serta keuangan, asuransi, dan real estate (SIC 6) karena perbedaan sifat laporan keuangan. Kedua, kecualikan data yang hilang untuk semua variabel dalam penelitian. Penelitian ini menggunakan model regresi berganda. Software yang digunakan dalam penelitian ini adalah Stata 14.0.

Berdasarkan hipotesis yang telah dikembangkan peneliti, persamaan model regresi yang digunakan penelitian ini sebagai berikut:

$$
\begin{aligned}
\mathrm{SGR}_{\mathrm{i}, \mathrm{t}}= & \alpha+\beta_{1} \mathrm{HCE}_{\mathrm{i}, \mathrm{t}}+\beta_{2} \mathrm{SCE}_{\mathrm{i}, \mathrm{t}}+\beta_{3} \mathrm{CEE}_{\mathrm{i}, \mathrm{t}}+ \\
& \beta_{4} \mathrm{FSIZE}_{\mathrm{i}, \mathrm{t}}+\beta_{5} \mathrm{LEV}_{\mathrm{i}, \mathrm{t}}+\mathrm{e} \\
\mathrm{ROE}_{\mathrm{i}, \mathrm{t}}= & \alpha+\beta_{1} \mathrm{HCE}_{\mathrm{i}, \mathrm{t}}+\beta_{2} \mathrm{SCE}_{\mathrm{i}, \mathrm{t}}+\beta_{3} \mathrm{CEE}_{\mathrm{i}, \mathrm{t}}+ \\
& \beta_{4} \mathrm{FSIZE}_{\mathrm{i}, \mathrm{t}}+\beta_{5} \mathrm{LEV}_{\mathrm{i}, \mathrm{t}}+\mathrm{e}
\end{aligned}
$$

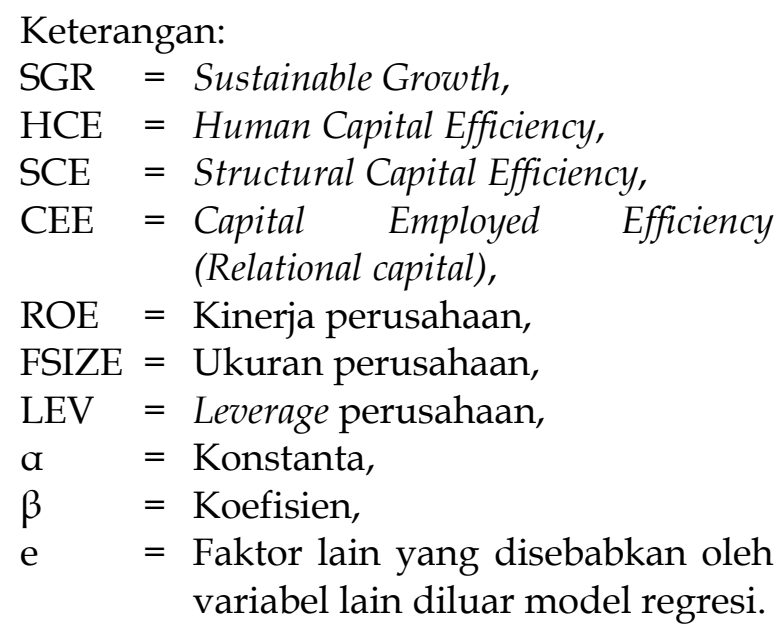

Mengacu pada penelitian sebelumnya penelitian ini melibatkan beberapa variabel yaitu (1) variabel terikat pertama adalah financial performance yang merupakan keberhasilan suatu perusahaan yang ditandai dengan return tahunan industri bersangkutan (Aprizal, 2018; Rakhiemah dan Agustia, 2009). Definisi ini sejalan dengan $\mathrm{Xu}$ dan Wang (2018) yang menggunakan ROE sebagai proksi dari kinerja perusahaan.
Rumus ROE yang digunakan adalah sebagai berikut:

$$
\mathrm{ROE}=(\text { Laba Bersih }) /(\text { Total Ekuitas })
$$

Variabel terikat kedua adalah sustainable growth yang merupakan tingkat maksimum dimana perusahaan dapat menggunakan dana internalnya sendiri untuk mencapai pertumbuhannya tanpa meminjam uang dari bank atau lembaga keuangan (Xu dan Wang, 2018). Sustainable growth dalam penelitian ini diproksikan dengan SGR atau sustainable growth rate. yang akan diukur dengan formula sebagai berikut:

\section{$\mathrm{SGR}=$ Net profit ratio $\mathrm{x}$ Asset turnover ratio $\mathrm{x}$ Retention rate $\mathrm{x}$ Financial leverage}

(2) variabel bebas yakni komponen dari intellectual capital yang diukur berdasarkan pada model VAICTM yang terdiri atas capital employed efficiency, human capital efficiency, dan structural capital efficiency. VAIC atau Value Added Intellectual Capital merupakan hasil penjumlahan antara Human Capital Efficiency (HCE), Structural Capital Efficiency (SCE), dan Capital Employed Efficiency (CEE).

Model pengukuran ini dimulai dengan menghitung nilai tambah yang diproksikan dengan VA. Value added atau VA akan digunakan untuk menghitung efisiensi masing-masing komponen intellectual capital. VA dirumuskan sebagai berikut:

$$
\mathrm{VA}=\mathrm{OUT}-\mathrm{IN}
$$

Keterangan:

$\mathrm{VA}=$ Nilai tambah

OUT $=$ Total pendapatan

IN = Total beban kecuali beban karyawan

Human capital dalam penelitian ini diproksikan dengan Human Capital Efficiency (HCE). Dalam penelitian Smriti dan Das (2018), HCE dirumuskan sebagai berikut:

$$
\mathrm{HCE} \quad=\mathrm{VA} / \mathrm{HC}
$$


Keterangan:

$\mathrm{HCE}=$ Rasio dari efisiensi VA terhadap $\mathrm{HC}$

$\mathrm{VA}=$ Nilai tambah

HC = Jumlah gaji dan upah

Strutural capital dalam penelitian ini diproksikan dengan Structural Capital Efficiency (SCE). Dalam penelitian Smriti dan Das (2018), SCE dirumuskan sebagai berikut:

Keterangan:

$$
\mathrm{SCE}=\mathrm{SC} / \mathrm{VA}
$$

SCE = Rasio dari SC terhadap efisiensi VA

$\mathrm{VA}=$ Nilai tambah

SC = Selisih antara VA dan HC

Relational capital dalam penelitian ini diproksikan dengan Capital Employed Efficiency (CEE). Dalam penelitian Smriti dan Das (2018), CEE dirumuskan sebagai berikut:

Keterangan:

$$
\mathrm{CEE}=\mathrm{VA} / \mathrm{CE}
$$

$\mathrm{CEE}=$ Rasio dari efisiensi $\mathrm{VA}$ terhadap CE

$\mathrm{VA}=$ Nilai tambah

$\mathrm{CE} \quad=$ Total ekuitas

(3) melibatkan beberapa variabel kontrol. Variabel kontrol yang digunakan pada penelitian ini leverage (LEV), dimana rasio yang digunakan perusahaan untuk meng- ukur seberapa jauh perusahaan menggunakan pendanaan menggunakan hutang (Brigham dan Houston, 2006). Leverage diukur melalui total hutang jangka pendek dan hutang jangka panjang dibagi total aset (Cabeza-Garcia et al., 2017). LEV dirumuskan sebagai berikut:

$$
\text { LEV }=\text { Total Hutang/Total Aset }
$$

Variabel kontrol kedua adalah ukuran perusahaan (SIZE), dimana perusahaan dengan ukuran besar, cenderung lebih mudah mendapatkan pendanaan. Berdasarkan penelitian $\mathrm{Xu}$ dan Wang (2018), ukuran perusahaan dalam penelitian ini akan diproksikan dengan FSIZE (firm size). FSIZE dirumuskan sebagai berikut:

$$
\mathrm{FSIZE}=\ln \text { total asset }
$$

\section{ANALISIS DAN PEMBAHASAN Analisis Statistik Deskriptif}

Uraian tabel 1 terkait hasil uji statistik deskriptif sebagai berikut:

Kinerja Perusahaan (ROE)

Kinerja perusahaan diukur menggunakan ROE dengan membagi laba bersih dan total ekuitas. ROE memiliki nilai ratarata 0,080 dan nilai standar deviasi 0,28. Nilai minimum ROE adalah $-1,137$ yaitu Central Proteina Prima Tbk tahun 2016, sedangkan nilai maksimum ROE adalah 1,381 perusahaan yang sama namun pada tahun yang berbeda yaitu Central Proteina Prima Tbk tahun 2018.

Tabel 1

Hasil Uji Statistik Deskriptif

\begin{tabular}{lcccc}
\hline \hline & Mean & Min & Max & Std. Deviation \\
\hline SGR & 0.203 & -9.726 & 4.397 & 1.520 \\
ROE & 0.080 & -1.137 & 1.381 & 0.280 \\
HCE & 1.448 & -8.044 & 6.432 & 1.840 \\
SCE & 0.397 & -4.040 & 6.870 & 1.120 \\
CEE & 0.264 & -0.838 & 1.683 & 0.340 \\
\hline
\end{tabular}

Sumber: Data Olah 2020 
Tabel 2

Hasil Uji Korelasi Pearson

\begin{tabular}{llllll}
\hline \hline & SGR & HCE & SCE & CEE & ROE \\
\hline SGR & 1.000 & & & & \\
HCE & $0.295^{* * *}$ & 1.000 & & & \\
& $(0.000)$ & & & & \\
SCE & 0.001 & -0.053 & 1.000 & & \\
& $(0.972)$ & $(0.155)$ & & & \\
CEE & $0.115^{* * *}$ & $0.359^{* * *}$ & $-0.068^{*}$ & 1.000 & \\
& $(0.002)$ & $(0.000)$ & $(0.072)$ & & \\
ROE & $0.373^{* * *}$ & $0.468^{* * *}$ & 0.050 & $0.684^{* * *}$ & 1.000 \\
& $(0.000)$ & $(0.000)$ & $(0.180)$ & $(0.000)$ & \\
\hline -values in parentheses ${ }^{*} p<0.1,{ }^{* * *} p<0.05,{ }^{* * *} p<0.01$ & \\
Sumber: Data Olahan, 2020 & & &
\end{tabular}

\section{Sustainable Growth (SGR)}

Sustainable growth diproksikan menggunakan sustainable growth rate yang diukur dengan mengalikan nilai profit retention rate, net profit margin, asset turnover, dan financial leverage. SGR memiliki nilai rata-rata 0,203 dan nilai standar deviasi 1,52. Nilai minimum SGR adalah $-9,726$ yaitu SLJ Global Tbk tahun 2017, sedangan nilai maksimum SGR adalah 4,397 dengan perusahaan yang sama namun pada tahun yang berbeda yaitu SLJ Global Tbk tahun 2016.

\section{Human Capital (HCE)}

Human capital (HCE) diukur dengan membagi antara nilai tambah (VA) dan human capital, dimana VA merupakan hasil dari menjumlahkan laba bersih dan beban gaji serta human capital merupakan jumlah gaji dan upah karyawan. HCE memiliki nilai rata-rata 1,448 dan nilai standar deviasi 1,84. Nilai minimum HCE adalah $-8,044$ yaitu Eterindo Wahanatama Tbk tahun 2017 dan nilai maksimum HCE adalah 6,432 yaitu Barito Pasific Tbk tahun 2017.

\section{Structural Capital (SCE)}

Structural capital (SCE) diukur dengan membagi antara nilai structural capital dan nilai tambah (VA), dimana structural capital adalah nilai selisih antara VA dan human capital. SCE memiliki nilai rata-rata 0,397 dan nilai standar deviasi 1,12. Nilai minimum SCE adalah $-4,040$ yaitu Multi
Prima Sejahtera Tbk tahun 2016 dan nilai maksimum SCE adalah 6,870 yaitu Asia Pasific Fibers Tbk tahun 2015.

\section{Relational Capital (CEE)}

Relational capital (CEE) diukur dengan membagi antara nilai tambah (VA) dan capital employed, dimana capital employed merupakan total ekuitas. CEE memiliki nilai rata-rata 0,264 dan nilai standar deviasi 0,34. Nilai minimum CEE adalah $-0,838$ yaitu Eterindo Wahanatama Tbk tahun 2016 dan nilai maksimum CEE adalah 1,683 yaitu SLJ Global Tbk tahun 2017.

\section{Uji Korelasi Pearson}

Uji Korelasi Pearson seperti tersaji pada tabel 2.

\section{Pengaruh Intellectual Capital terhadap Sustainable Growth}

Berdasarkan tabel 3, persamaan regresi linear berganda untuk model pertama dapat disusun sebagai berikut:

\section{SGR $=1.582+0.251 \mathrm{HCE}+0.016 \mathrm{SCE}-$ $0.084 \mathrm{CEE}+\mathrm{e}$}

Persamaan tersebut menunjukkan bahwa human capital (HCE) berpengaruh signifikan terhadap sustainable growth (SGR) dengan p-value sebesar 0,005 lebih kecil daripada tingkat signifikansi 0,05 . Koefisien sebesar 0,251 menunjukkan jika human capital (HCE) naik sebesar satu satuan maka 
sustainable growth (SGR) akan naik sebesar 0,251 . Structural capital (SCE) tidak memiliki pengaruh signifikan terhadap sustainable growth (SGR) dengan p-value sebesar 0,777 lebih besar daripada tingkat signifikansi 0,05. Relational capital (CEE) juga tidak berpengaruh signifikan terhadap sustainable growth (SGR). Hal tersebut berdasarkan $p$ value CEE sebesar 0,857 lebih besar daripada tingkat signifikansi 0,05.

Tabel 3

Hasil Regresi Linier Model 1

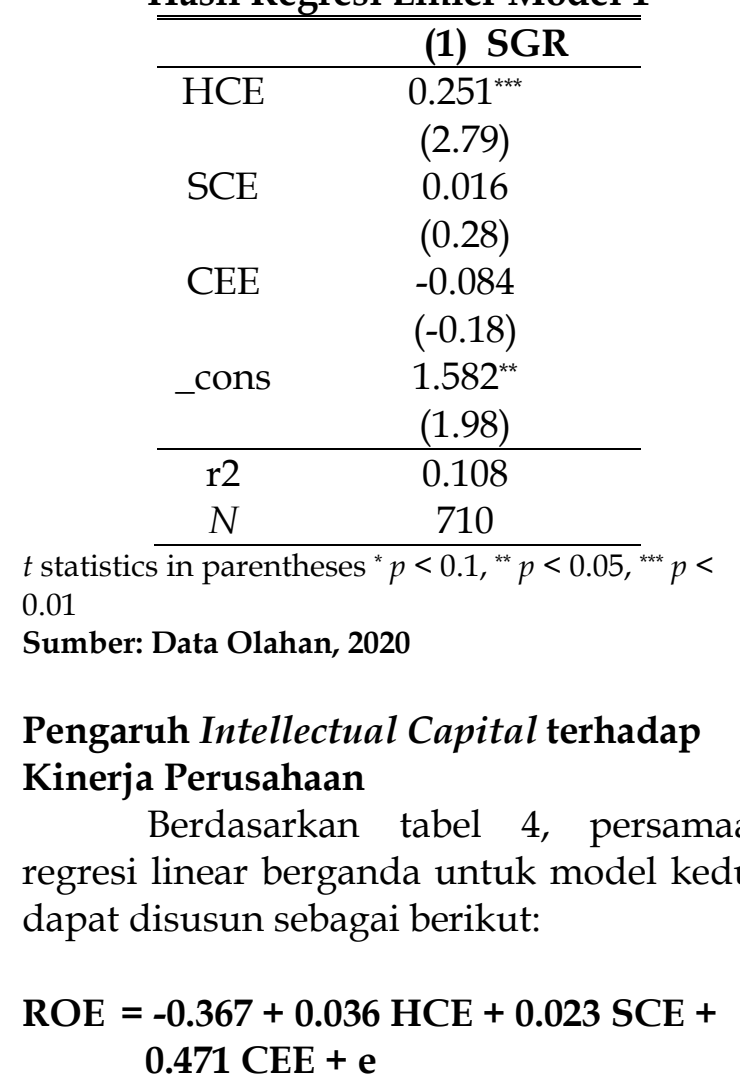

Persamaan tersebut menunjukkan bahwa human capital (HCE) berpengaruh signifikan terhadap kinerja perusahaan (ROE) dengan p-value sebesar 0,000 lebih kecil daripada tingkat signifikansi 0,05. Koefisien sebesar 0,036 menunjukkan jika human capital (HCE) naik sebesar satu satuan maka kinerja perusahaan (ROE) akan naik sebesar 0,036. Structural capital (SCE) juga menunjukkan adanya pengaruh signifikan terhadap kinerja perusahaan (ROE) dengan p-value sebesar 0,048 lebih kecil daripada tingkat signifikansi 0,05. Koefisien sebesar 0,023 menunjukkan jika structural capital (SCE) naik sebesar satu satuan maka kinerja perusahaan (ROE) akan naik sebesar 0,023. Relational capital (CEE) memiliki $p$-value sebesar 0,000 lebih kecil daripada tingkat signifikansi 0,05 , artinya CEE juga berpengaruh signifikan terhadap kinerja perusahaan (ROE). Koefisien sebesar 0,471 menunjukkan jika relational capital (CEE) naik sebesar satu satuan maka kinerja perusahaan (ROE) akan naik sebesar 0,471.

Tabel 4

Hasil Regresi Linier Model 2

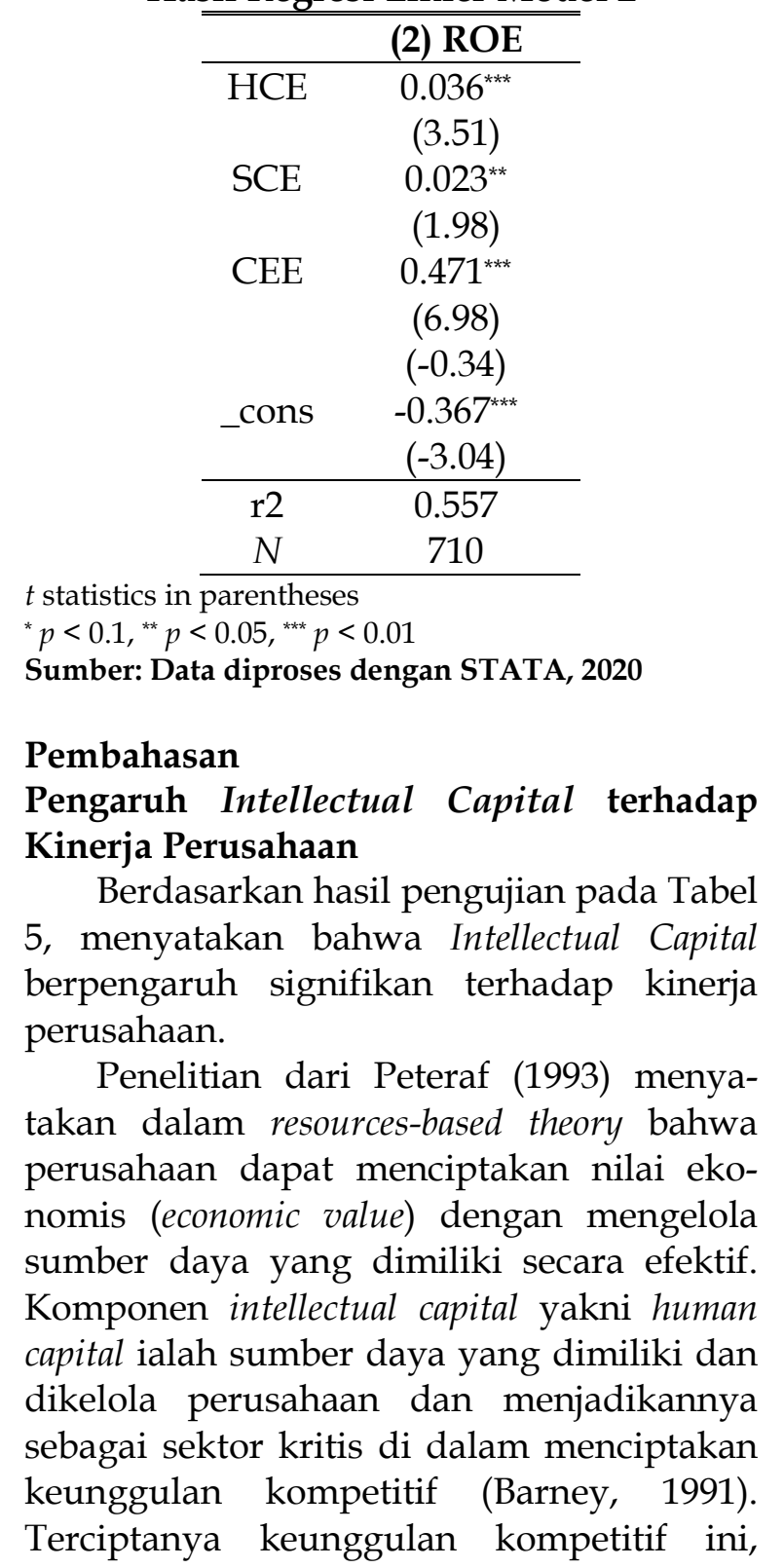


dapat tersampaikan nilai perusahaan tersebut kepada pihak eksternal perusahaan. Nimtrakoon (2015) dan Ginesti et al. (2018) juga menjelaskan bahwa intellectual capital ditemukan sebagai penggerak nilai pada perusahaan.

Structural capital ialah aset tidak berwujud yang dimiliki perusahaan sebagai penggerak nilai internal perusahaan seperti prosedur aktivitas perusahaan, budaya perusahaan, database, serta struktur perusahaan. Mengingat bahwa structural capital merupakan salah satu aset tidak berwujud yang dimiliki perusahaan dan diterapkan oleh perusahaan, namun jarang disadari oleh pihak eksternal sehingga mendorong manajemen perusahaan untuk memanfaatkan human capital menjadi penggerak structural capital, karena nilai structural capital memegang presentase lebih tinggi dari nilai perusahaan (Edvinsson dan Sullivan, 1996). Terakhir, relational capital mewakili pengetahuan yang tertanam di dalam suatu perusahaan untuk menciptakan hubungan eksternal yang baik (Marti, 2001), hubungan eksternal yang baik dapat diciptakan melalui informasi mengenai apa yang telah dilakukan oleh manajemen untuk merealisasikan keinginan pihak eksternal (Besley dan Brigham, 2008).

Berdasarkan tiga komponen pada intellectual capital bertujuan untuk menjalankan strategi perusahaan dengan memaksimalkan sumber daya yang dimiliki sehingga mampu meningkatkan nilai perusahaan melalui inovasi-inovasi yang berkelanjutan. Hal ini sesuai dengan penelitian terdahulu yang dilakukan oleh Berzkalne dan Zelgalve (2014); Li dan Zhao (2017); Ma and Osiyevskyy (2017) menyatakan bahwa intellectual capital memiliki pengaruh terhadap nilai perusahaan. Intellectual capital yang tidak dimanfaatkan dengan baik dapat menyebabkan kesalahan pemilihan strategi sehingga berdampak negatif bagi nilai perusahaan (Forte et al., 2017; Kalkan et al., 2014).

\section{Pengaruh Human Capital terhadap Kinerja Perusahaan}

P-value sebesar 0,000 lebih kecil dari tingkat signifikansi 0,05 dan nilai koefisien sebesar 0,036. Berdasarkan hasil pengujian pada Tabel 6, maka hipotesis 2a yang menyatakan human capital berpengaruh signifikan terhadap kinerja perusahaan diterima. Berdasarkan hasil pengujian analisis statistik human capital berpengaruh signifikan terhadap kinerja perusahaan. Hal tersebut dapat dilihat dari hasil pengujian yang menunjukkan nilai signifikansi sebesar 0,000. Artinya semakin tinggi human capital maka kinerja perusahaan akan semakin meningkat. Hasil penelitian ini sejalan dengan Bontis et al. (2018), Nimtrakoon (2015), serta Andreeva dan Garanina (2016) yang menyatakan keberadaan human capital mampu mendorong kinerja perusahaan.

Tabel 5

Hasil Uji Regresi hipotesis 1

\begin{tabular}{cllc}
\hline \hline Variabel & Koefisien & P-Value & Simpulan \\
\hline Intellectual Capital & 0.004 & 0.086 & Berpengaruh positif, signifikan \\
\hline Sumber: Data Olahan, 2020 & &
\end{tabular}

Tabel 6

Hasil Pengujian Hipotesis 2a

\begin{tabular}{cllc}
\hline \hline Variabel & Koefisien & P-Value & Simpulan \\
\hline Human Capital & 0.036 & 0.000 & Berpengaruh positif, signifikan \\
\hline
\end{tabular}

Sumber: Data Olahan, 2020 
Resource-based view theory menekankan sumber daya perusahaan harus memenuhi empat kriteria yaitu bernilai, langka, tidak dapat ditiru, dan tidak ada sumber daya pengganti agar menjadi sumber daya yang unik dan memiliki keunggulan kompetitif (Barney, 1991). Keberadaan karyawan mampu menjadi salah satu sumber daya yang unik dan modal bagi perusahaan untuk memiliki keunggulan kompetitif. Sejalan dengan Neha dan Das (2018) dalam penelitiannya menyebutkan bahwa karyawan merupakan aset penting bagi perusahaan dan human capital merupakan gabungan dari keterampilan, kemampuan, pengalaman, dan keahlian karyawan. Apabila keberadaan karyawan dapat dimaksimalkan, dengan memberinya pelatihan untuk terus mengembangkan kemampuannya tentu saja akan menghasilkan karyawan dengan kompetensi yang baik. Dengan kompetensi yang baik ini nantinya, akan meningkatkan kinerja para karyawan dan tentu mendorong kinerja perusahaan untuk semakin baik. Hasil penelitian ini tidak sejalan dengan penelitian yang dilakukan oleh Ginesti et al. (2018) yang menyatakan bahwa human capital tidak berpengaruh signifikan terhadap kinerja perusahaan.

\section{Pengaruh Structural Capital terhadap Kinerja Perusahaan \\ P-value sebesar 0.048 lebih kecil dari tingkat signifikansi 0.05 dan nilai koefisien sebesar 0.023. Berdasarkan hasil pengujian pada tabel 7 , maka hipotesis $2 b$ yang menyatakan structural capital berpengaruh signifikan terhadap kinerja perusahaan di- terima. Berdasarkan hasil pengujian analisis}

statistik structural capital berpengaruh signifikan terhadap kinerja perusahaan. Hal tersebut dapat dilihat dari hasil pengujian yang menunjukkan nilai signifikansi sebesar 0.048 yang nilainya lebih kecil daripada 0.05 . Artinya semakin tinggi nilai dari structural capital maka kinerja perusahaan akan semakin meningkat. Hasil penelitian ini sejalan dengan Ginesti et al. (2018) serta Andreeva dan Garanina (2016) yang menyatakan keberadaan structural capital mampu mendorong kinerja perusahaan.

Dalam resource-based view theory, perusahaan harus mampu mengelola aset yang dimiliki dengan baik untuk menciptakan keunggulan kompetitif bagi perusahaan. Structural capital dapat diartikan sebagai salah satu sumber daya yang mampu menjadikan perusahaan memiliki keunggulan bersaing dan mengarahkan perusahaan untuk memiliki kinerja yang baik sesuai dengan teori RBV. Hal tersebut dikarenakan structural capital merupakan infrastruktur dan elemen yang dibutuhkan untuk menunjang sumber daya yang berguna bagi keberlanjutan perusahaan yang meliputi struktur, rencana, database dan sistem perusahaan (Bontis et al., 2018; Neha dan Das, 2018). Jika perusahaan belum mampu memanfaatkan structural capital dengan baik akan menyebabkan pemilihan strategi perusahaan yang kurang tepat dan secara tidak langsung juga akan berpengaruh terhadap kinerja perusahaan. Hasil penelitian ini tidak sejalan dengan Bontis et al. (2018) serta Neha dan Das (2018) yang menyatakan bahwa structural capital tidak berpengaruh terhadap kinerja perusahaan.

Tabel 7

Hasil Pengujian Hipotesis $2 b$

\begin{tabular}{cllc}
\hline \hline Variabel & Koefisien & P-Value & Simpulan \\
\hline Structural Capital & 0.023 & 0.048 & Berpengaruh positif, signifikan \\
\hline Sumber: Data Olahan, 2020 & &
\end{tabular}


Tabel 8

Hasil Pengujian Hipotesis 2c

\begin{tabular}{cllc}
\hline \hline Variabel & Koefisien & P-Value & Simpulan \\
\hline Relational Capital & 0.471 & 0.000 & Berpengaruh positif, signifikan \\
\hline Sumber: Data Olahan, 2020 & &
\end{tabular}

Tabel 9

Hasil Pengujian Hipotesis 3

\begin{tabular}{cllc}
\hline \hline Variabel & Koefisien & P-Value & Simpulan \\
\hline Intellectual Capital & 0,003 & 0,857 & Tidak berpengaruh, signifikan \\
\hline Sumber: Data Olahan, 2020 & &
\end{tabular}

\section{Pengaruh Relational Capital terhadap Kinerja Perusahaan}

P-value sebesar 0.000 lebih kecil dari tingkat signifikansi 0.05 dan nilai koefisien sebesar 0.471. Berdasarkan hasil pengujian pada tabel 8, maka hipotesis 2c yang menyatakan relational capital berpengaruh signifikan terhadap kinerja perusahaan diterima. Berdasarkan hasil pengujian analisis statistik relational capital berpengaruh signifikan terhadap kinerja perusahaan. Hal ini dibuktikan dengan nilai signifikansi sebesar 0.048 yang nilainya lebih kecil daripada 0.05. Artinya semakin tinggi nilai yang dihasilkan dari relational capital akan menghasilkan kinerja perusahaan yang semakin baik. Hasil penelitian ini sejalan dengan penelitian Ginesti et al. (2018) serta Neha dan Das (2018) yang menyatakan keberadaan relational capital mampu mendorong kinerja perusahaan.

Relational capital mengacu pada pengelolaan hubungan eksternal perusahaan yang meliputi hubungan dengan pemasok, pelanggan, serta pemangku kepentingan (Neha dan Das, 2018). Menurut Andreeva dan Garanina (2016) menjaga hubungan dengan pihak eksternal merupakan hal yang penting untuk menunjang keberlangsungan perusahaan. Hal ini sesuai dengan teori RBV, kemampuan perusahaan dalam mengelola aset dengan baik akan mengantarkan perusahaan pada keunggulan kompetitif. Relational capital sebagai salah satu elemen intellectual capital merupakan aset penting bagi perusahaan yang harus dikelola dengan baik agar perusahaan mencapai keunggulan kompetitif dan memiliki kinerja yang baik. Hasil penelitian ini tidak sejalan dengan hasil penelitian dari Nimtrakoon (2015) serta Andreeva dan Garanina (2016) yang menyatakan tidak adanya pengaruh relational capital terhadap kinerja perusahaan.

\section{Pengaruh Intellectual Capital terhadap Sustainable Growth}

Berdasarkan hasil pengujian pada Tabel 9 menyatakan bahwa Intellectual Capital tidak berpengaruh signifikan terhadap Sustainable Growth.

Konsep sustainable growth (SGR) menggambarkan pertumbuhan optimal dari perspektif keuangan dengan mengasumsikan strategi yang diberikan dengan kondisi kerangka keuangan yang jelas. Secara sederhana, perusahaan dapat menggunakan dana internal untuk mencapai pertumbuhannya tanpa meminjam uang dari bank atau lembaga keuangan. Dalam konteks Industri 4.0, modal inovatif (R\&D dan hak kekayaan intelektual) adalah penentu alokasi sumber daya internal, pengembangan produk baru, dan perluasan pasar baru. Kegiatan R\&D dengan risiko tinggi mengharuskan perusahaan untuk membuat jaminan sistem yang saling berintegrasi, dan SC dapat memberikan jaminan lingkungan untuk 
pertumbuhan perusahaan manufaktur. Disisi lain, untuk perusahaan manufaktur, HC dan SC adalah sumber daya unik yang sulit ditiru oleh pesaing. Oleh karena itu, IC adalah kekuatan pendorong utama untuk pertumbuhan perusahaan manufaktur yang berkelanjutan. Kesesuaian dengan stakeholder theory perusahaan tidak hanya beroperasi untuk kepentingan sendiri tetapi harus memberikan manfaat bagi stakeholder seperti pemegang saham, konsumen, supplier, masyarakat, pemerintah dan pihak lainnya. Hal ini menuntut pengelolaan yang baik dan maksimal atas seluruh potensi yang dimiliki perusahaan, agar menciptakan value added yang selanjutnya akan mendorong kinerja perusahaan untuk mencapai sustainable growth. Keberadaan teori stakeholder membantu manajer perusahaan mengerti lingkungan perusahaan mereka dan melakukan pengelolaan perusahaan yang lebih efektif.

\section{Pengaruh Human Capital terhadap Sustainable Growth}

P-value sebesar 0.005 lebih kecil dari tingkat signifikansi 0.05 dan nilai koefisien sebesar 0.251. Berdasarkan hasil pengujian pada tabel 10, maka hipotesis 4a yang menyatakan human capital berpengaruh signifikan terhadap sustainable growth diterima. Berdasarkan hasil pengujian analisis statistik human capital berpengaruh signifikan terhadap sustainable growth. Hal tersebut dapat dilihat dari hasil pengujian yang menunjukkan nilai signifikansi sebesar 0.005. Artinya semakin tinggi human capital maka sustainable growth perusahaan akan semakin meningkat. Hasil penelitian ini sejalan dengan Xu dan Wang (2018) serta $\mathrm{Xu}$ et al. (2020) yang menyatakan human capital berpengaruh positif terhadap sustainnable growth, dimana value added dari human capital dapat meningkatkan nilai sustainable growth.

Menurut Barney (1991), teori RBV menyatakan perusahaan memiliki sumber daya yang menjadikan perusahaan memiliki keunggulan bersaing dan mampu menciptakan kinerja yang baik dalam jangka panjang. Untuk mencapai hal tersebut, sumber daya harus dikelola dengan baik. Salah satu sumber daya tersebut adalah human capital. Kemudian keberadaan teori stakeholder membantu manajer perusahaan mengerti lingkungan perusahaan mereka dan melakukan pengelolaan perusahaan yang lebih efektif. Manajer harus mengelola organisasi untuk keuntungan seluruh stakeholder. Sebagai salah satu elemen dari intellectual capital, human capital merupakan modal utama dalam menjalankan kegiatan perusahaan. Human capital didefinisikan sebagai pengetahuan, keterampilan, dan pengalaman dari karyawan serta motivasi dan komitmen dari karyawan untuk berkontribusi pada perusahaan (Andreeva dan Garanina, 2016). Dari pengetahuan, motivasi serta komitmen para karyawan inilah melahirkan inovasi dan ide kreatif yang berguna untuk menunjang kegiatan perusahaan. Dengan memaksimalkan kemampuan dan kompetensi karyawan, human capital menjadi salah satu aset perusahaan untuk memiliki keunggulan bersaing sehingga sustainable growth akan tercapai. Penelitian ini tidak sejalan dengan penelitian yang telah dilakukan oleh Mukherjee dan Sen (2019) yang menyatakan bahwa human capital tidak berpengaruh signifikan terhadap sustainable growth.

Tabel 10

Hasil Pengujian Hipotesis 4a

\begin{tabular}{cllc}
\hline \hline Variabel & Koefisien & P-Value & Simpulan \\
\hline Human Capital & 0.251 & 0.005 & Berpengaruh positif, signifikan \\
\hline Sumber: Data Olahan, 2020 & &
\end{tabular}


Tabel 11

Hasil Pengujian Hipotesis $4 b$

\begin{tabular}{cllc}
\hline Variabel & Koefisien & P-Value & Simpulan \\
\hline Structural Capital & 0.016 & 0.777 & Berpengaruh positif, tidak signifikan \\
\hline
\end{tabular}

Sumber: Data Olahan, 2020

Tabel 12

Hasil Pengujian Hipotesis 4c

\begin{tabular}{cllc}
\hline Variabel & Koefisien & $\boldsymbol{P}$-Value & Simpulan \\
\hline Relational Capital & -0.084 & 0.857 & Berpengaruh negatif, tidak signifikan
\end{tabular}

Sumber: Data Olahan, 2020

\section{Pengaruh Structural Capital terhadap Sustainable Growth}

P-value sebesar 0.777 lebih besar dari tingkat signifikansi 0.05 dan nilai koefisien sebesar 0.016. Berdasarkan hasil pengujian pada tabel 11, maka hipotesis $4 \mathrm{~b}$ yang menyatakan structural capital berpengaruh signifikan terhadap sustainable growth ditolak. Berdasarkan hasil pengujian analisis statistik structural capital tidak berpengaruh signifikan terhadap sustainable growth. Hal tersebut dapat dilihat dari hasil pengujian yang menunjukkan nilai signifikansi sebesar 0.777 yang nilainya lebih besar daripada 0.05. Hasil ini menyiratkan bahwa sustainable growth tidak terkait dengan structural capital. Penelitian ini sejalan dengan penelitian $\mathrm{Xu}$ et al. (2020) yang menyatakan structural capital tidak berpengaruh terhadap sustainable growth.

Structural capital adalah segala infrastruktur penunjang yang mendukung jalannya operasional perusahaan dan produktivitas karyawan, dimana meliputi prosedur, database, rutinitas, dan budaya perusahaan (Meles et al., 2016). Keberadaan structural capital merupakan hasil dari sistem perusahaan yang telah tercipta dari waktu ke waktu dan akan tetap bersama perusahaan walaupun dengan orang-orang yang berbeda. Oleh karena itu, structural capital di perusahaan Indonesia cenderung menghasilkan value added yang tergolong kecil. Hal inilah yang menyebabkan structural capital tidak mampu mempengaruhi sustainable growth secara signifikan.

Hasil penelitian ini tidak sejalan dengan Xu dan Wang (2018) serta Mukherjee dan Sen (2019) yang menyatakan dengan keberadaan structural capital akan membawa pengaruh yang signifikan terhadap sustainable growth.

\section{Pengaruh Relational Capital terhadap Sustainable Growth}

P-value sebesar 0.857 lebih besar dari tingkat signifikansi 0.05 dan nilai koefisien sebesar -0.084. Berdasarkan hasil pengujian pada tabel 12, maka hipotesis 4c yang menyatakan relational capital berpengaruh signifikan terhadap sustainable growth ditolak. Berdasarkan hasil pengujian analisis statistik relational capital tidak berpengaruh signifikan terhadap sustainable growth. Hal tersebut dapat dilihat dari hasil pengujian yang menunjukkan nilai signifikansi sebesar 0.857 yang nilainya lebih besar daripada 0.05 . Hasil penelitian ini sejalan dengan pendapat Andreeva dan Garanina (2016) yang menyatakan keberadaan relational capital tidak memberikan pengaruh yang signifikan terhadap kinerja perusahaan, sehingga mengindikasikan juga tidak berpengaruh terhadap sustainable growth.

Relational capital mengacu kepada nilai tambah yang dihasilkan organisasi dalam hubungan dengan pelanggan, pemasok, dan 
pemangku kepentingan lainnya (Andreeva dan Garanina, 2016). Penyebab tidak berpengaruhnya relational capital terhadap sustainable growth adalah perusahaan tidak memanfaatkan keberadaan modal ini secara maksimal. Terbukti dengan rata-rata nilai yang dimiliki relational capital paling kecil dibandingkan kedua modal lainnya. Hal ini mengindikasikan hubungan perusahaan dengan pihak eksternal dan pemangku kepentingan belum berjalan optimal. Sejalan dengan pendapat Andreeva dan Garanina (2016), bahwa relational capital membutuhkan waktu untuk mengembangkan hubungan-hubungan dengan pihak eksternal dan stakeholder.

Hasil penelitian ini tidak sejalan dengan penelitian $\mathrm{Xu}$ dan Wang (2018) serta Mukherjee dan Sen (2019) yang menyatakan dengan keberadaan relationl capital akan membawa pengaruh yang signifikan terhadap sustainable growth.

\section{SIMPULAN DAN SARAN}

Berdasarkan pada hasil analisis dari penelitian ini dapat disimpulkan bahwa intellectual capital yang dimiliki oleh perusahaan akan menjadi pendorong bagi keberlanjutan perusahaan tersebut. Hasil penelitian ini menunjukkan bahwa human capital berpengaruh signifikan terhadap sustainable growth. Structural capital dan relational capital tidak berpengaruh signifikan terhadap sustainable growth. Hasil penelitian juga menunjukkan bahwa human capital dan structural capital berpengaruh signifikan terhadap kinerja perusahaan. Relational capital berpengaruh signifikan terhadap kinerja perusahaan.

Hal ini dikarenakan komponen dari intellectual capital yang dimiliki oleh perusahaan yakni human capital, structural capital, dan relational capital mampu meningkatkan kinerja perusahaan sehingga mampu menarik minat investor untuk beinvestasi pada perusahaan tersebut. Investasi ini tentunya akan meningkatkan harga saham perusahaan yang akan berpengaruh pada nilai perusahaan tersebut. Selain, intellectual capital yang dimiliki oleh perusahaan mampu meningkatkan kinerja perusahaan, intellectual capital juga menjadi pendorong bagi perusahaan untuk terus tumbuh berkelanjutan, khususnya pada human capital yang dimiliki oleh perusahaan. Oleh karena itu, perusahaan harus memperhatikan dan terus mengembangkan sumber daya yang dimiliki guna untuk memajukan perusahaan dan menjadikan perusahaan unggul dalam bersaing.

Hasil penelitian ini diharapkan mampu memberikan kontribusi literasi terhadap akademisi maupun praktisi tentang intellectual capital, kinerja perusahaan dan sustainable growth. Selain itu, diharapkan mampu membantu para pela$\mathrm{ku}$ bisnis untuk memahami pentingnya intellectual capital dalam menunjang proses bisnis perusahaan untuk meningkatkan kinerja dan menciptakan sustainable growth perusahaan. Peneliti selanjutnya dapat mempertimbangkan proksi lain yang digunakan untuk mengukur kinerja perusahaan seperti NPM, serta model pengukuran lain bagi sustainable growth seperti model Van Horne.

\section{DAFTAR PUSTAKA}

Amouzesh, N., Z. Moeinhar, dan Z. Mousavi. 2011. Sustainable Growth Rate and Firm Performance: Evidence from Iran Stock Exchange. International Journal of Business and Social Science 2(23): 249-255.

Andreeva, T. dan T. Garanina. 2016. Do All Elements of Intellectual Capital Matter for Organizational Performance? Evidence from Russian Context. Journal of Intellectual Capital 17(2): 397-412. doi: 10.1108/jic-07-2015-0062.

Anghel, I., M. Siminica, M. Cristea, M. Sichigea, dan G. G. Noja. 2018. Intellectual Capital and Financial Performance of Biotech Companies in the Pharmaceutical Industry. Amfiteatru Economic, 20(49): 631-646. doi:10.24818/ ea/2018/49/631. 
Aprizal. 2018. Orientasi Pasar dan Keunggulan Bersaing: Studi Kasus Penjualan Komputer. Celebes Media Perkasa. Makassar.

Arora, L., S. Kumar, dan P. Verma. 2018. The Anatomy Sustainable Growth Rate of Indian Manufacturing Firms. Global Business Review 19(4): 1-22.

Barney, J. B. 1991. Firm Resource and Sustained Competitive Advantage. Advances in Strategic Management 17: 203227.

Besley, S. dan E. F. Brigham. 2008. Essentials of Managerial Finance. United States of America: Thomson South-Western. Riyanto, Bambang.

Berzkalne, I. dan E. Zelgalve. 2014. Intellectual Capital and Company Value. Procedia - Social and Behavioral Sciences 110: 887-896. https://doi.org/ 10.1016/j.sbspro.2013.12.394.

Bontis, N. 2001. Assessing Knowledge Assets: A Review of the Models Used to Measure Intellectual Capital. International Journal of Management Review 3(1): 41-60.

Bontis, N., W. C. C. Keow, dan S. Richardson. 2000. Intellectual Capital and Business Performance in Malaysian Industries. Journal of Intellectual Capital 1(1): 85-100. https://doi.org/10.1108/ 14691930010324188.

Bontis, N., M. Ciambotti, F. Palazzi, dan F. Sgro. 2018. Intellectual Capital and Financial Performance in Social Cooperative Enterprise. Journal of Intellectual Capital 19(4): 712-731. https://doi.org/ 10.1108/JIC-03-2017-0049.

Brigham, E. F. dan J. F. Houston, 2006. Fundamentals of Financial Management. Ninth Edition. Horcourt College. United States of America.

Cabeza-Garcia, L., M. Sacristan-Navarro, dan S. Gomez-Anson. 2017. Family Involvement and Corporate Social Responsibility Disclosure. Journal of Family Business Strategy (8): 109-122.

Cantele, S. dan A. Zardini. 2018. Is Sustainability a Competitive Advantage for
Small Businesses? An empirical Analysis of Possible Mediators in the Sustainability Financial Performance Relationship. Journal of Cleaner Production 182: 166-176. doi:10.1016/j.jclepro. 2018.02.016.

Duff, A. 2018. Intellectual Capital Disclosure: Evidence from UK Accounting Firms. Journal of Intellectual Capital 19(4): 768-786. https://doi.org/10.1108/JIC06-2017-0079.

Dzenopoljac, V., C. Yaacoub, N. Elkanj, dan N. Bontis. 2017. Impact of Intellectual Capital in Corporate Performance: Evidence from the Arab Region. Journal of Intellectual Capital 18(3): 884-903.

Edvinsson, L. dan P. Sullivan. 1996. Developing a Model for Managing Intellectual Capital. European Management Journal 14(4): 356-364.

Fahmi, I. 2012. Analisis Kinerja Keuangan. Alfabeta. Bandung.

Forte, W., J. Tucker, G. Matonti, dan G. Nicolo. 2017. Measuring the Intellectual Capital of Italian Listed Companies. Journal of Intellectual Capital 18(4): 710732. https://doi.org/10.1108/JIC-082016-0083.

Freeman, R. E. 1984. Strategic Management: A Stakeholder Approach. Pitman. Boston.

Ginesti, G., A. Caldareli, dan A. Zampela. 2018. Explorig the Impact of Intellectual Capital on Company Reputation and Performance. Journal of Intellectual Capital 19(5): 915-934. doi:10.1108/JIC01-2018-0012.

Ghozali, I. dan A. Chariri. 2007. Teori Akuntansi. Badan Penerbit Universitas Diponegoro. Semarang.

Herrmann, C., C. Schmidt, D. Kurle, S. Blume, dan S. Thiede. 2014. Sustainability in Manufacturing and Factories of the Future. International Journal of Precision Engineering and ManufacturingGreen Technology 1(4): 283-292. doi:10. 1007/s40684-014-0034-z.

Ismail, K. N. I. K. dan M. A. Karem. 2011. Intellectual Capital and the Financial Performance of Bank in Bahrain. Journal 
of Business Management and Accounting 1(1): 63-77.

Jordao, R. V. D. dan V. R. d. Almeida, V. R. de. 2017. Performance Measurement, Intellectual Capital and Financial Sustainability. Journal of Intellectual Capital 18(3): 643-666. https://doi.org/ 10.1108/JIC-11-2016-0115.

Kalkan, A., O. C. Bozkurt, dan M. Arman. 2014. The Impacts of Intellectual Capital, Innovation, and Organizational Strategy on Firm Performance. Social and Behavioral Sciences: 700-707.

Kasmir. 2015. Analisis Laporan Keuangan. Rajawali Pers. Jakarta.

Khalique, M., N. Bontis, J. A. N. b. Shaari, J., dan A. H. Md. Isa. 2015. Intellectual Capital in Small and Medium Enterprises in Pakistan. Journal of Intellectual Capital 16(1): 224-238. http://doi.org/ 10.1108/JIC-01-2014-0014.

Li, Y. dan Z. Zhao. 2018. The Dynamic Impact of Intellectual Capital on Firm Value: Evidence from China. Applied Economics Letters: 19-23.

Marti, J. M. V. 2001. ICBS-Intellectual Capital Benchmarking System. Journal of Intellectual Capital 2(2): 148-164.

Midiantari, P. N. dan D. Agustia. 2020. Impact of Intellectual Capital on Firm Value through Reputation as a Mediating Variable. Journal of Security and Sustainability Issues 9(4): 1203- 1213.

Meles, A. C. Porzio, G. S. Naro, dan V. Verdoliva. 2016. The Impact of Intellectual Capital Efficiency on Commercial Banks Performances: Evidence from US. Journal of Multinational Financial Management 36(Sept): 64-74.

Mukherjee, T. dan S. S. Sen. 2019. Intellectual Capital and Corporate Sustainable Growth: The Indian Evidence. Asian Journal of Business Environment 9(2): 5-15.

Neha, S. dan N. Das. 2018. The Impact of Intellectual Capital on Firm Performance: A Study of Indian Firms Listed in COSPI. Journal of Intellectual Capital 19(5): 935- 964.
Nimtrakoon, S. 2015. The Relationship between Intellectual Capital, Firms' Market Value and Financial Performance. Journal of Intellectual Capital 16(3): 587-618. doi:10.1108/jic-09-20140104.

Ozkan, N., S. Cakan, dan M. Kayacan. 2016. Intellectual Capital and Financial Performance: A Study of the Turkish Banking Sector. Borsa Istanbul Review 17(3): 190-198.

Ma, Q. dan O. Osiyevskyy. 2017. Maximizing the Strategic Value of Corporate Reputation: A Business Model Perspective. Strategy and Leadership 45(4): 24-32. https://doi.org/10. 1108/SL-05-2017-0043.

Peteraf, M. A. dan J. B. Barney. 2003. Unraveling the Resource-Based Tangle. Managerial and Decision Economics, 24: 309-323. DOI: 10.1002/mde.1126.

Peteraf, M. A. 1993. The Cornerstones of Competitive Advantage: A ResourceBased View. Strategic Management Journal 14: 179-191.

Rakhiemah, A. N. dan D. Agustia. 2009. Pengaruh Kinerja Lingkungan terhadap CSR Disclosure dan Kinerja Finansial Perusahaan Manufaktur yang Terdaftar di Bursa Efek Indonesia. Simposium Nasional Akuntansi XII: 4-6.

Sharabati, A. A. A., S. N. Jawad, dan N. Bontis. 2010. Intellectual Capital and Business Performance in the Pharmaceutical Sector of Jordan. Management Decision 48(1): 105-131. doi:10.1108/ 00251741011014481.

Smriti, N. dan N. Das. 2018. The Impact of Intellectual Capital on Firm Performance: A Study of Indian Firms Listed in COSPI. Journal of Intellectual Capital 19(5): 935-964. doi:10.1108/jic-11-20170156.

Ulum, I. 2015. Intellectual Capital: Model Pengukuran, Framework Pengungkapan, dan Kinerja Organisasi. UMM Press. Malang.

Uzliawati, L. dan K. Djati. 2015. Intellectual Capital Disclosure, Corporate Gover- 
nance Structure and Firm Value in Indonesian Banking Industry. International Journal of Monetary Economics and Finance 8(2): 162-177.

$\mathrm{Xu}$, J. dan B. Wang. 2018. Intellectual Capital, Financial Performance and Companies' Sustainable Growth: Evidence from Korean Manufacturing Industry. Sustainability 10: 4651.

Xu, X. L., H. H. Chen, dan R. R. Zhang. 2020. The Impact of Intellectual Capital Efficiency on Corporate Sustainable
Growth-Evidence from Smart Agriculture in China. Agriculture 10(6): 199214.

Yaseen, S. G., D. Dajani, dan Y. Hasan. 2016. The Impact of Intellectual Capital on the Competitive Advantage: Applied Study in Jordanian Telecommunication Companies. Computers in Human Behavior 62: 168-175. doi:10.1016/j.chb. 2016.03.075 